\title{
JEJAK KEPEMIMPINAN ORANG SUNDA: PEMAKNAAN AJARAN DALAM NASKAH CARITA PARAHYANGAN (1580)
}

\author{
THE TRACES OF THE SUNDANESE LEADERSHIP: \\ THE TEACHING OF THE TENETS IN CARITA PARAHYANGAN MANUSCRIPT
}

(1580)

\author{
Agus Heryana \\ Balai Pelestarian Nilai Budaya Bandung \\ Jl. Cinambo 136 Ujungberung Bandung \\ e-mail: agus.yana17@yahoo.co.id
}

\begin{abstract}
Abstrak
Naskah Carita Parahiyangan ditulis sekitar tahun 1580 M merupakan kelompok naskah sejarah. Penelitian yang didasarkan pada kajian sejarah tentu sudah dilakukan yang kemudian memunculkan nama raja, kerajaan dan masa kekuasaannya. Berbeda dengan itu, penelitian atas naskah - yang akan dilakukan ini - tidak pada eksistensi kerajaan, melainkan terfokus pada ajaran kepemimpinannya. Apa yang mendasari keberhasilan dan keruntuhan sebuah kerajaan? Adakah ajaran yang menjadi pegangan dalam membangun masyarakatnya. Pengkajian ajaran kepemimpinan dalam teks naskah Carita Parahiyangan menggunakan kajian anaslisis isi mengingat teks merupakan deskripsi naratif. Di samping itu, digunakan pula metode intertekstual yakni menelusuri teks dari teks naskah lain yang sezaman atau yang ada sebelumnya. Dalam hal ini adalah naskah Siksakandang Karesian dan naskah Amanat (dari) Galunggung. Hasil yang diperoleh adalah pemerintahan kerajaan itu terkait dengan ajaran yang dipegangnya. Baik buruknya seorang raja (pemimpin) sangat erat dengan ketaatan, kepatuhan atau pelanggaran terhadap ajaran. Ajaran yang muncul pada masa kerajaan Sunda adalah sebagaimana terdapat dalam ajaran Siksakandang karesian dan Amanat dari Galunggung.
\end{abstract}

Kata kunci: ajaran, kepemimpinan, Carita Parahiyangan.

Carita Parahyangan is a historical script, written about 1580 BC. The research based on the study of history would have done by another researcher which is raising the name of the king, kingdom, and power. Differently, this study of the manuscript - which will be done - is not on the existence of the kingdom, but rather focused on the teaching of leadership. What constitutes success and collapse of an empire does? Are there any teachings of the grip in a building community? This research focused on teaching leadership in the Carita Parahiyangan manuscript uses study of the text which is considering the text is narrative description. In addition, the intertextual method is also used to search a text of the other contemporary manuscript text or previously exist. In this case the previous manuscripts are Siksakandang Ngkaresian and Amanat (from) Galunggung. The result of this study is the Kingdom is related to the holding of the teaching. Pros and cons of a king (leader) are very close with the obedience, compliance or violation of the tenets. The tenets which is appeared in the era of Sundanese kingdom is like what it has been founded in the tenets of Siksakandang Ngkaresian and Amanat dari Galunggung manuscript.

Keywords: tenets, leadership, Carita Parahiyangan. 


\section{A. PEN DAHULUAN}

Tinjauan bahasa menunjukkan kata "pemimpin" dan "kepemimpinian" berasal dari kata pimpin yang berarti mengantar, menuntun, membawa dengan memegang tangan yang dibawa. Pemimpin adalah kata benda yang berarti orang yang melakukan pimpin; sedangkan kepemimpinan merupakan kata sifat, sesuatu yang diletakan / disifatkan pada orang yang memimpin (pemimpin). Dengan demikian, kedua kata tersebut, pemimpin dan kepemimpinan, adalah dua kata yang saling berhubungan dalam hal makna mengantar, menuntun, membawa dengan memegang tangan yang dibawa.

Dalam tinjauan sosiologi pemimpin dan kepemimpinan tidaklah sekedar menuntun, seperti pengertian asal kata, tetapi di dalamnya terkandung kemampuan atau kekuasaan atas pihak lain. Arti kekuasaan itu sendiri adalah kemampuan satu pihak (subjek kekuasaan) untuk mempengaruhi pihak lain (objek kekuasaan), sehingga pihak lain bertindak sesuai dengan kehendak dan tujuan subjek kekuasaan (pemegang kekuasaan) (Soekanto,1988: 265)

Pemegang kekuasaan bukan orang sembarangan, melainkan orang yang memiliki jabatan tertentu dalam pemerintah atau kedudukan tinggi dalam struktrus masyarakat. Orang dimaksud biasanya disebut pemimpin. Hal itu berarti budaya kekuasaan adalah tindakan pemimpin yang dilakukan dalam menjalankan kepemimpinannya. Dengan kata lain, budaya kekuasaan mengacu pada sikap dan tindakan pemimpin atas dasar kedudukannya. Dan hasilnya sangat bergantung pada karakter atau sifat pemimpinnya (karakternya).

Kapankah pemimpin lahir ?

Sebuah peristiwa yang menggelitik nurani kita terjadi manakala perintah seorang sesepuh kampung lebih didengar (baca: ditaati) ketimbang perintah seorang pejabat pemerintahan. Perintah "ustad kampung" lebih didengar dari pada perintah kepala kantornya sendiri. Lebih kontras lagi adalah perintah "orang pintar" lebih ditaati ketimbang parintah orang tua sendiri. Pertanyaan mendasar adalah mengapa hal itu terjadi ? Apa yang istimewa dari sesepuh dan ustad kampung serta orang pintar tersebut ? Bukankah seorang kepala mempunyai kekuasaan dan kewenangan atas sejumlah staf karyawannya, bahkan bertanggung jawab atas "mati hidupnya", namun kenyataannya seringkali tidak diindahkan semua perintahnnya.

Seseorang gampang sekali menjadi seorang kepala. Secarik surat keputusan dari seorang mentri di sebuah departemen, misalnya, telah cukup untuk mengangkat seorang tersebut menjadi kepala kantor. Demikian pula seorang direktur dengan kewenangannya, dapat saja pada saat itu mengangkat kepala divisi $X$ di perusahaannya. Namun dapatkah seorang mentri dan atau seorang direktur "mengangkat" seorang pemimpin? Apakah seorang pemimpin itu lahir karena bakat dan guratan nasibnya ataukah hasil "rekayasa" sebuah sistem ?

M. Ryaas Rasyid (1996:1) secara sederhana mendefinisikan pemimpin adalah seseorang yang terus menerus membuktikan bahwa ia mampu mempengaruhi sikap dan tingkah-laku orang lain, lebih dari kemampuan mereka (orang lain itu) mempengaruhi dirinya. Kepemimpinan, dengan demikian, adalah sebuah konsep yang merangkum berbagai segi dari interaksi pengaruh antara pemimpin dengan pengikut dalam mengejar tujuan bersama. Di sini diasumsikan bahwa suasana kepemimpinan hanya mungkin terbentuk dalam suatu lingkungan yang secara dinamis melibatkan hubungan diantara sejumlah orang. Konkritnya, seseorang hanya bisa mengaku dirinya sebagai pemimpin atau dianggap oleh pihak lain sebagai pemimpin, jika ia memiliki sejumlah pengikut.

Pemimpin merupakan sosok yang "unik", yang lahir membawa angin segar, yang ditangannya tergenggam resep dan 
obat bagi umatnya yang menderita. Seorang pemimpin tidaklah akan berunjuk diri bahwa dirinya adalah pemimpin. Tetapi gelar pemimpin diucapkan oleh para pendukungnya. Namun demikian, ajaran Islam mengisyaratkan bahwa setiap orang itu adalam pemimpin. Artinya setiap insan harus mempertanggungjawabkan perbuatannya kepada sesamanya semasa ia hidup di dunia ini, dan kelak kepada Tuhan setelah ia meninggal dunia. Jadi, dalam hal ini, setiap diri manusia memiliki fitrah untuk menjadi seorang pemimpin. Minimalnya, dalam lingkup kecil, ia menjadi pemimpin keluarga.

Jauh sebelum para pemimpin bangsa lahir, para leluhur bangsa Indonesia telah memberikan petuah dan rambu-rambu di dalam mempimpin bangsa. Berbagai kerajaan timbul tenggelam mengikuti kepemimpinan seorang raja. Sebuah kerajaan mencapai kejayaan disebabkan pemimpinnya (rajanya) memiliki kemampuan untuk itu. Sebaliknya keruntuhan sebuah kerajaan pun disebabkan oleh rajanya yang tidak mampu memimpin rakyatnya mencapai kejayaan. Diantara sekian amanat dan petuah para leluhur yang ada di Indonesia, terekam jejaknya dalam catatan-catatan naskah kuno salah satunya adalah orang Sunda.

Catatan-catatan naskah kuno orang Sunda tidaklah secara khusus mengurai tentang kepemimpinan seorang raja. Uraian kepemimpinan tersebar pada beberapa naskah dan dibungkus dalam bentuk ajaran. Ajaran akan berbuah manis manakala dilaksanakan secara nyata oleh pengikutnya, tetapi ajaran pun akan berasa pahit manakala ditinggalkan pengikutnya.

Kata ajaran berasal dari kata “ajar". Artinya petunjuk yang diberikan kepada orang supaya diketahui (diturut). Ajaran sebagai kata benda adalah (1) segala sesuatu yang diajarkan dapat berupa nasihat, petuah maupun petunjuk; (2) paham, pandangan (KBBI, 2013). Penganut kepercayaan terhadap Tuhan Yang Maha Esa sering menyebut ajaran dengan tuntunan. Ajaran atau tuntunan adalah petunjuk agar orang memahami dan mengerjakan dengan sebaik-baiknya. Ajaran atau tuntunan di dalamnya mengandung nilai-nilai luhur yang mengejawantahkan keyakinan terhadap Tuhan Yang Maha Esa (Ensiklopedi, 2010:31). Dalam bahasa Sunda arti ajaran mengacu pada padanan kata ageman yang berarti cecekelan nu hade (pedoman yang baik) (Danadibrata, 2006:7). Adiwimarta (1993: 130) memberi batasan ajaran dalam arti umum, yaitu segala sesuatu yang diajarkan dapat berupa nasihat, petuah, petunjuk, anjuran atau pun imbauan.

Ajaran yang berisi petuah atau nasihat dari leluhur suatu masyarakat itu tersebar dan tersimpan dalam tradisi tulis nusantara yakni naskah-naskah kuna. Naskah sebagai tinggalan budaya tidaklah sekadar catatan tanpa makna. Tulisan dalam bentuk aksara-aksara tertentu di dalamnya memiliki arti dan makna penting bagi sosial kebudayaan sebuah masyarakat pada masanya. Salah satunya adalah ajaran yang merupakan sebagian kandungan khasanah naskah nusantara. Ajaran dalam naskah berperan sebagai pedoman berperilaku, bertindak atau bersikap bagi suatu masyarakat tertentu.

Adapun fungsinya adalah memberikan pendidikan (didaktik), menjaga terah/ kehormatan, dan membentuk manusia ideal menurut ajarannya. Dalam kalimat lain fungsi naskah (ajaran) sebagaimana dikemukakan Ikram (1997:171) adalah pertama, adalah motivasi untuk menghidupkan ingatan kepada keluarga dan kedudukannya dalam masyarakat, menekankan kehebatan dan jasa mereka. Kedua, adalah gambaran manusia dalam sosok yang ideal, termasuk nilai moral dan perilakunya, yang nampaknya berkaitan dengan agama atau pandangan hidup tertentu. Misalnya, naskah-naskah Sunda yang berisi tentang sejarah daerah setempat yang umumnya mengutamakan penyebutan nama penguasa daerah setempat beserta leluhur, keluarga, dan keturunannya mempunyai fungsi 
sebagai pegangan kalangan menak setempat, baik pegangan yang memberikan keterangan tentang silsilah keluarga pemegang naskah maupun pegangan tentang ajaran hidup yang dicontohkan dan diamanatkan oleh leluhurnya (Ekadjati, 1982: 276-279).

Beralih pada naskah-naskah Sunda periode masa kuna (Ekadjati,1988: 10) diperoleh informasi bahwa orang Sunda di masa lampau sangat mengutamakan halhal yang berhubungan dengan kehidupan keagamaan, kebudayaan, dan akhlak. Hampir semua naskah menitikberatkan uraiannya kepada segi kerohanian, bukan kepada hal-hal yang lebih bersifat jasadi (Ayatrohaedi,1995:33).

Naskah Carita Parahyangan (CP) dalam Katalog Sunda termasuk periode masa kuna. Sesungguhnya CP bukanlah naskah ajaran, melainkan naskah kelompok sejarah yang menginformasikan raja-raja yang pernah berkuasa di wilayah Sunda. Namun demikian, dalam hal-hal tertentu tersembul peristiwa, atau dialog yang mengandung ajaran-ajaran. Ajaran atau peristiwa itu selalu berhubungan dengan tindakan atau ucapan raja-raja Sunda masa itu.

\section{B. METOdE PENELITIAN}

Naskah CP ditulis dalam aksara Sunda dan bahasa Sunda Kuna. Berasal dari daerah Galuh dan sekarang disimpan di Perpustakaan Nasional, Jakarta pada Kropak 406. Banyaknya halaman dan nomor urut terbesar angka 47, tiap lembar berukuran 21 X $3 \mathrm{~cm}$, terdiri atas 2 X 4 larik tulisan, kecuali lembar ke-29, ditulis hanya sebelah (recto). Nomor urut dikerjakan oleh Cohen Stuart, namun tanpa memerhatikan jalan ceritanya (Atja, 1981: i, cf. Pleyte, 1911: 196).

Pengerjaan transkripsi telah dilakukan oleh para ahli di bidangnya yaitu; K.F. Holle, C.M. Pleyte, R.M.Ng. Poerbatjaraka, H. Ten Dam dan J. Noorduyn. Alih aksara secara keseluruhan dari pekerjaan Poerbatjaraka, dengan memerhatikan pendapat-pendapat $H$. Ten
Dam dan J. Noorduyn telah diterbitkan dengan terjemahan dan bahasan dalam Bahasa Sunda (1968) dan dalam Bahasa Indonesia bersama Saleh Danasasmita (1981) (Atja, 1990: 8). Sehubungan dengan tulisan ini, teks naskah $\mathrm{CP}$ yang dijadikan objek kajian adalah teks naskah CP yang telah diterjemahkan ke dalam Bahasa Indonesia bersama Saleh Danasasmita (1981).

Teks naskah CP berbentuk paparan (deskriptif) tentang raja-raja Sunda pada masa itu. Bentuk data yang bersifat deskripsi tersebut sering dianalisis menurut isinya dan karena itu analisis macam ini disebut juga analisis isi (content analysis) (Supardi, tt: 87).

Selain itu, digunakan pula metode intertekstual sebatas mengetengahkan informasi yang dirujuk teks (CP). Dalam pengertian informasi yang terdapat dalam teks CP dijelaskan oleh teks lain yang sezaman. Oleh karena itu, bukanlah kebetulan sebuah karya sastra baru mendapatkan makna hakikinya bila diajarkan atau dipertentangkan dengan karya sebelumnya. Seringkali karya sastra itu tercipta karena menanggapi, menyerap, dan mentransformasikan karya sastra sebelumnya. (Riffaterre, cf. Teeuw, 1983:65).

\section{HASIL DAN BAHASAN \\ 1. Eksistensi Kerajaan Sunda pada A bad ke-8 s.d. Abad ke-16}

Naskah Carita Parahiyangan (CP) pada dasarnya menunjuk pada wilayah bagian barat Pulau Jawa, yang terdiri atas kerajaan-kerajaan kecil; dua buah kerajaan daripadanya muncul dan senantiasa bersaing sepanjang berdirinya, ialah Kerajaan Galuh dan Kerajaan Sunda. Kadangkadang kedua kerajaan itu bermusuhan, tetapi acapkali juga dipersatukan di bawah seorang maharaja, kalau dalam keadaan bersatu sebagai sebuah kerajaan biasanya dikenal sebagai Kerajaan Sunda, walaupun maharajanya bersemayan di wilayah Galuh, misalnya, ketika kerajaan itu di bawah Prabu Niskalawastu Kancana (1371-1475 M), dalam pada itu di Sunda 
sebagai raja wilayah diperintah oleh Prabu Susuktunggal, sedangkan di Galuh berkuasa Prabu Dewaniskala, keduanya putra Prabu Niskalawastu Kancana, tetapi berlainan ibunya (Atja,1990: 8).

Secara garis besar kandungan $\mathrm{CP}$ menyangkut keberadaan kerajaan-kerajaan yaitu Sunda (Bogor), Pakuan Pajajaran (Bogor), Galuh (Kawali), Saunggalah (Kuningan). Kerajaan-kerajaan ini mengalami dinamisasi, jatuh-bangun, yang sama dalam masa pemerintahannya. Dalam arti keruntuhan dan kejayaan sebuah pemerintahan disebabkan perebutan kekuasaan atau pelanggaran terhadap pedoman hidup bernegara dan bermasyarakat. Di lain pihak penyatuan kerajaan yang terpisah bisa terjadi tanpa pertumpahan darah yakni melalui hubungan kekeluargaan dalam bentuk perkawinan. Sebagai contoh, Sri Baduga Maharaja atau Prabu Siliwangi.

Sri Baduga Maharaja yang semasa kecilnya bernama Jayadewata, oleh ayahnya, Wastu Kancana, dinikahkan dengan putri Susuktunggal yaitu Kentring Manik Mayang Sunda yang dalam lakon pantun kadang-kadang disebut Padmawati. Pernikahan ini merupakan "garis kebijakan" Wastu Kancana agar wilayah kerajaannya kelak tidak terpecah-pecah. (Danasasmita, 1984:1-2).

\section{Dinamisasi Kerajaan}

Naskah CP secara sederhana memberi keterangan akan penyebab penggantian seorang raja. Keterangannya itu ditandai dengan frase: gering lampah (salah peri-laku), lantaran polahna resep ngarusak nu tapa (sebab kelakuannya senang merusak kebaikan), lantaran salah lampah daek ngala awewe ku awewe (sebab buruk kelakuannya, senang mengambil wanita dengan memperalat wanita lain), lantaran ratu lampahna cilaka ku awewe (sebab raja celaka oleh wanita), mindeng maehan jalma tanpa dosa (sering membunuh orang tanpa dosa), ngarampas tanpa rasrasan (merampas hak orang tanpa perikemanu-siaan), hanteu hormat ka kolot (tidak menghormati orang tua), ngahina pandita (menghina kaum agamawan).

Ti dinya Sang Manarah ngadeg ratu di Jawa, mangrupa persembahan. Nurutkeun carita Jawa, Rahiang Tamperan lilana ngadeg raja tujuh taun, lantaran polahna resep nga-rusak nu tapa, mana teu lana nyekel kakawasaanana oge. Sang Manarah, lilana jadi ratu dalapanpuluh taun, lantaran tabeatna hade. Sang Manisri lilana jadi ratu geneppuluh taun, lantaran pengkuh ngagem Sanghiang Siksa (CP XV)

(Kemudian Sang Manarah menjadi raja di Jawa Pawatan (nama tem-patnya) menurut ucapan Jawa. Rahiyang Tanperan menjadi raja selama 7 tahun, karena kelakuannya senang membinasakan orang yang sedang bertapa. Oleh karena itu ia tidak lama menjadi raja. Sang Manarah menjadi raja selama 80 tahun, karena sempurna menunaikan kewajiban agama. Sang Manisri menjadi raja selama 60 tahun, karena memerhatikan Sanghiyang Siksa)

Rahiang Banga lawasna ngadeg ratu tujuh taun, lantaran polahna hanteu didasarkeun kana adat kabiasaan anu bener. Rakean di Medang lilana ngadeg ratu tujuh taun. Rakeanta Diwus lilana jadi ratu opatlikur taun. Rakeanta Wuwus lilana jadi ratu tujuhpuluh dua taun. Nu hilang di Hujung Cariang lilana jadi ratu taun, kaopatna teu cucud, lantaran salah lampah, daek ngala awewe ku awewe. ..... Prebu Datia Maharaja lilana jadi ratu tujuh taun. $\mathrm{Nu}$ hilang di winduraja lilana jadi ratu tilulikur taun. Nu hilang di Kreta lawasna jadi ratu salapanpuluhdua taun, lantaran ngukuhan kana lampah anu hade, ngadatangkeun gemah ripah. Diganti deui ku nu hilang di Winduraja, henteu lila ngadegna ratu ngan dalapan welas taun. (CP XVII)

(Rahiyang Banga menjadi raja selama 7 tahun, karena perilakunya tidak mengikuti 
agama secara benar. Rakeyanta di Medang men-jadi raja selama 7 tahun. Rakeyanta Diwus menjadi raja selama 24 tahun. Rakeyanta Wuwus menjadi raja selama 72 tahun. Sang Lumahing Hujung Cariang menjadi raja selama 3 tahun. Tahun keempat turun tahta buruk kelakuannya, senang mengambil wanita de-ngan memperalat wanita lain.

Sang Lumahing Kreta menjadi raja selama 92 tahun, karena bepegang teguh kepada perbuatan utama, mengalami jaman keemasan. Digantikan lagi oleh Sang Lumahaing Winduraja. Tidak lama bertahta menjadi raja selama 18 tahun).

Diganti ku Sang Ratusakti Sang Mangabatan di Tasik. Enya eta anu hilang ka Pengpelengan. Lilana jadi ratu dalapan taun, lantaran ratu lampahna cilaka $k u$ awewe. Larangan ti kaluaran jeung $k u$ indung tere. Mindeng maehan jalma tanpa dosa, ngarampas tanpa rasrasan, hanteu hormat ka kolot, ngahina pandita. Ulah diturut ku nu pandeuri, lampah ratu kitu mah. Tah kitu riwayat sang ratu teh. (CP XXII)

(Diganti oleh Sang Ratusakti Sang Mangabatan di Tasik, yaitu yang dipusarakan ke Pengpelengan. Menjadi raja selama 8 tahun, akibat perilakunya kena bencana oleh wanita larangan dari luar dan oleh ibu tiri. Ia membunuh orang-orang tak bersalah, me-rampas hak orang tanpa pera-saan, tidak berbakti kepada orang tua, menghina para pen-deta. Jangan ditiru oleh (keturunan) yang kemudian kelakuan raja ini. Itulah riwayat nyata Sang Prabu Ratu. )

Sang Nilakendra, dilantarankeun lila teuing dina kasenangan, ngumbar hawa napsu. Bogana anak, kana hatena geus kaancikan $k u$ rekadaya, nya nurunkeun pertapa, incu pateterean. Inuman keras dianggapna saperti cai wujudna godaan napsu. Jelema nu ngahuma rewog baranghakan, teu gumbira lamun teu pepela-kan. Lila ratu ngalajur napsu dina barang dahar, teu nurut-keun adat kabiasaan, enggoning ngumbar kasenangan borak borak da nganggap saluyu jeung kabeungharanana. Lilana jadi ratu genep welas taun (CP XXIV).

(Sang Nilakendra, kerjanya tiada lain kecuali bersenang-senang selamanya, akhirnya menyebar kemaksiatan. Mempunyai anak, perhatiannya tertimbun dengan kenikmatan dunia. Menurunkan pertapa, cucu saudara tirinya. Air penyebab kemabukan dijadikan pelezat makan dan minum. Peladang rakus akan makanan. Tidak senang bila bercocok tanam. Terlalu lama raja tergoda oleh makanan. Tidak ada ilmu yang disenanginya kecuali makanan yang serba lezat yang pantas untuk ukuran kekayaannya. menjadi raja selama 16 tahun

Intisari amanat kutipan $\mathrm{CP}$ di atas adalah keruntuhan sebuah kerajaan disebabkan pemimpinnya sudah tidak lagi berorintasi pada kehidupan akhirat. Mereka lebih mementingkan kesenangan pribadi ketimbang kesejaheraan rakyatnya. Namun demikian, perhatian penuh pada kehidupan akhirat pun bukan hal yang baik. Pada awal keruntuhan kerajaan Pajajaran yang dipimpin oleh Ratu Dewata, Carita Parahiyangan memberikan catatan negatif atas perilakunya yang berdiam diri atas serangan pasukan yang tambuh sangkane (tidak dikenal identitasnya). Dalam keadaan negara diancam musuh ia melakukan tapa brata dengan bertarak, (berdiam diri, acuh) padahal tapa seorang raja adalah: memerintah dengan baik.

Tindakan Ratu Dewata lumaku ngarajaresi (berlaku seperti petapa) tidak pada tempatnya dalam keadaan negara menghadapi serangan musuh. Karena itulah penulis CP menyindir, Nya iyatnayatna sang kawuri, haywa ta sira kabalik pupuasaan (Ya berhati-hatilah orang-orang yang kemudian, janganlah engkau kalah perang karena rajin puasa) (Danasasmita,1983-1984 Jilid Keempat: 
27-28). Demikian pula untuk raja-raja yang berperilaku sewenang-wenang, penulis $\mathrm{CP}$ memperingatkan kepada generasi penerus dengan ucapan : Ulah diturut $k u \quad n u$ pandeuri, lampah ratu kitu mah (jangan ditiru oleh kita perilaku raja demikian).

\section{Syarat Pemimpin}

\section{1) Memiliki kekuatan}

Seorang pemimpin selalu berhubungan dengan kekuasaan yang diperolehnya melalui kekuatan atau kemampuan dirinya. Dalam hal tertentu, pemimpin harus tampil di garis depan dengan disertai keberanian "mengalirkan darah". Artinya, kekerasan, atau ketegasan bertindak diperlukan untuk mencapai tujuan. Berikut adalah peristiwa Sanjaya ditantang untuk membuktikan kesaktiannya dan kemampuan mengalahkan kerajaan lain.

Carek Rahiang Sanjaya:

"Patih, indit sia, tanyakeun ka

Batara Dangiang Guru, saha

kituh anu pantes pikeun

nyekel pamarentahan di

urang ayeuna."

Sadatangna patih $\mathrm{ka}$

Galunggung, carek Batara

Dangiang Guru: "Na aya

pibejaeun

naon, patih?"

"Pangampura, kami teh

diutus ku Rahiang Sanjaya,

menta nu bakal marentah, adi

Rahiang purbasora."

Hanteu dibikeun ku Batara

dangiang Guru.

Carek Batara Dangiang

Guru: "Rahiang Sanjaya,

indit beunangkeun $\mathrm{ku}$

sorangan.

Elehkeun Guruhaji

Pagerwesi, elehkeun Wulan,

Sang Tumanggal, elehkeun

Guruhaji

Tepus jeung elehkeun

Guruhaji Balitar. Jig indit

Rahiyang Sanjaya; elehkeun
Sang

Wulan, Sang Tumanggal,

Sang Pandawa di Kuningan.

Maranehna meunang

kasaktian,

nu ngalantarankeun Sang

Wulan, Sang Tumanggal,

Sang Pandawa di Kuningan

henteu

kabawah ku dangiang Guru.

Lamun kaelehkeun bener

maneh sakti."

Rahiang Sanjaya tuluy perang

ka Kuningan. Eleh Rahiang

Sanjaya diuberuber, nepi ka

walungan Kuningan. Rahiang

Sanjaya undur.

(CP IX, Atja:1968)

(Kata Rahiyang Sanjaya:"Sang

Patih, pergilah engkau !

Tanyakan kepada Batara

Dangiyang Guru, siapa yang

akan memerintah di sini !"

Setiba sang patih di

Galunggung, kata Batara

Dangiyang Guru: "Apa

kabarmu, Sang Patih?"

"Maaf, aku disuruh oleh

Rahiyang Sanjaya meminta

calon pemegang

pemerintahan, yaitu adik

Rahiyang Purbasora."

Tidak diberikan oleh

Batara Dangiyang Guru.

Kata Batara Dangiyang

Guru: "Rahiyang Sanjaya

harus pergi menguji diri.

Kalahkan Guru Haji

Pagerwesi, kalahkan

Guruhaji Mananggul,

kalahkan Guru Haji Tepus,

kalahkan Guru Haji Balitar.

Pergilah Rahiyang Sanjaya,

kalahkan Sang Wulan,

Sang Tumanggal, Sang

Pandawa di Kuningan,

tidak dikuasai Dangiyang

Guru. Bila mampu 
mengalahkannya, terbuktilah kesaktiannya.

Rahiyang Sanjaya pergi ke

Kuningan, lalu diperangi.

Kalah rahiyang Sanjaya.

Dikejar sampai di Sungai

Kuningan. Rahiyang

Sanjaya mundur).

\section{2) Pemimpin harus sehat jasmani rohani}

Sehat jasmani dalam pengertian tidak cacat badan dan sehat rohani berarti bisa membedakan baik dan buruk, salah dan benar, merupakan syarat mutlak yang harus dimiliki seorang pemimpin. Naskah CP menginformasikan dua orang raja yang gagal naik tahta disebabkan cacat tubuh, yaitu Rahiang Sempakwaja dan Rahiyang Kidul. Hal itu tergambarkan pada kalimat :
(Nelah) Rahiang
Wereh, nu matak
disebut kitu, waktu
ditilar, adi lanceuk
masih laleutik
keneh.Teu tulus jadi
ratu, lantaran
(huntuna) rohang,
mangkana katelah
Rahiang Sempakwaja.
Rahiyang Kidul oge
hanteu bisa jadi ratu
sabab burut, nya jadi
Wikuraja. (CP
XI,Atja:1968)
(Rahiyang Wereh
sebab dinamai
demikian, sebab pada
masa ditinggalkan
(oleh ayahnya)
sebagai anak kakak-
beradik, tidak dapat
menjadi raja karena
ompong. Karena
itulah ia dinamai
Sempakwaja.
Rahiyang Kidul pun
urung menjadi ratu

karena hernia, lalu

menjadi wikuraja.

\section{3 ) Pendidikan}

Keberhasilan seorang pemimpin erat kaitannya dengan pendidikannya. Keberhasilan pendidikan sangat bergantung pula kepada kualitas guru yang bersangkutan. Seorang Wastukencana, tidaklah akan menjadi besar dan wangi namanya manakala ia tidak didik oleh seorang guru yang saleh, yaitu Sang Bunisora. Ia ditinggal wafat ayahnya, Prabu Linggabuana, pada usia 9 tahun. Ayahnya meninggal pada peristiwa Bubat tahun $1357 \mathrm{M}$.

Usia yang masih muda tidak memungkinkan menjabat kedudukan sebagai Raja Sunda. Oleh karena itu pemerintahan dipegang oleh pamannya, Sang Bunisora. Sang Bunisora sebagai raja Sunda ia bergelar Prabu Batara Guru Pangadiparamarta Janadewabrata. la disebut juga Batara Guru di Jampang, bahkan ada pula yang menyebutnya Prabu Kuda Lalean.

Prabu Bunisora sangat tekun mendalami agama sehingga ia dipandang sebagai seorang raja-pendeta. Penulis Carita Parahiyangan menggelarinya satmata. Satmata adalah tahap kelima dari tujuh tingkatan batin yang merupakan tingkat tertinggi bagi seseorang yang masih ingin mencampuri urusan dunia. Di bawah asuhannya, Wastu Kancana menerima didikan yang lengkap. la mendapat bimbingan pengetahuan kenegaraan dan keagamaan (Danasasmita, 1983-1984. Jilid Ketiga: 37).

Menurut kropak 630 tingkat batin manusia dalam pendalaman agama adalah: acara, adigama, gurugama, tuhagama, satmata, surakloka, nirawerah. Satmata adalah tingkat kelima dan tahap tertinggi bagi seseorang yang masih ingin mencampuri urusan duniawi. Setelah mencapai tingkat keenam (surakloka) orang sudah menertawakan dunia (sinis terhadap kehidupan umum), dan pada tingkat ketujuh (nirawerah) akan padamlah 
segala hasrat dan nafsu. Tingkat satmata itulah yang telah dicapai Batara Guru di Jampang.

\section{4) Musyawarah}

Setelah lama berperang. Rahiang Sanjaya sudah merasa lelah dan sudah saatnya untuk berdamai. Oleh karena itulah, ia kemudian bermusyawarah untuk membagikan wilayah kekuasaannya.

Carek Rahiang Sanjaya: "Na naon nu jadi karempan teh? Ayeuna aing hayang runtut raut. Aing jeung bapa, Rahiang Kuku, Sang Seuweukarma. Ayeuna aing moal ngalawan. Ayeuna urang tetepkeun: tanah bagian Dangiang Guru di tengah, bagian Rangiang Isora ti Wetan; jauhna nepi ka kalereun Paraga jeung Cilotiran, ti Kulon Tarum, ka Kulon bagian Tohaan di Sunda." Sanggeus Rahiangtang Kuku mulang ka Arile, sadatangna ka Arile, putus hancana di dunya, hilang dina umur nu kacida kolotna. (CP XIV, Atja:1968).

(Ujar Rahiang Sanjaya,"Apa yang menjadi halangan? Sekarang aku ingin berdamai. Aku dan bapak Rahiang Kuku, Sang Seuweukarma. Sekarang aku tidak akan melawan. Mari kita tetapkan tanah bagian Dangiang Guru di tengah, bagian Rangiang Isora dari Timur; luasnya hingga ke utara Paraga dan Cilötiran, dari Barat Tarum, ke Barat bagian Tohaan di Sunda." Setelah Rahiang-tang Kuku kembali ke Arile, setibanya ke Arile, ia wafat, meninggal dunia pada umur tua).

\section{Ruh Kepemimpinan: agama atau ajaran}

Dalam naskah CP tercatat sekurangkurangnya empat orang raja yang dikatakan berpegang kepada ajaran Sanghyang Siksa, yaitu: Rahyang Sanjaya, Rahyang Manisri, Prabu Darmasiksa, dan Prabu Jayadewata. Carita Parahiyangan menunjukkan adanya para wiku "nu ngawakan Jati Sunda" yaitu para pendeta yang khusus mengamalkan "agama Sunda" dan memelihara "kabuyutan parahiyangan". Sisa dari kabuyutan Jati Sunda atau
Parahiyang seperti itu adalah Mandala Kanekes yang dihuni "orang Baduy" sekarang (Danasasmita,1983-84. Jilid Keempat:39-41).

Dalam pada itu, terdapat nama ajaran yang menjadi sumber pedoman dalam menjalankan pemerintahan atau pengabdian kepada manusia, yaitu Watang Ageung, Sanghyang Siksa, Ajaran Prabuguru Darmasiksa, dan Ajaran Mahaprabu Nila Wastukancana.

\section{1) Watang Ageung}

Ngangaranan manéh Rahiyangta

Déwaraja. Basa lumaku ngarajarési ngangaranan manéh Rahiyangta ri Medangjati, inya Sang Layuwatang, nya nu nyieun Sanghiyang Watang Ageung (CP I, Atja:1968)

(Sang Kandiawan kemudian menamakan dirinya Rahiyangta Dewaraja. Ketika ia menjadi rajaresi, menamakan dirinya Rahiyangta di Medangjati, yaitu Sang Layuwatang. Dialah yang menyusun Sanghiyang Watang Ageung)

Kutipan bagian awal dari naskah CP menyebutkan adanya nama Sanghiyang Watang Ageung. Nama ini juga terdapat pada naskah Para Putera Rama dan Rawana dan Bujangga Manik, tetapi dengan kata lain yaitu apus ageung. Watang (Ageung) adalah kitab agung atau sejenis teks suci atau teks keagamaan yang dalam cerita Para Putera Rama dan Rawana menjelma menjadi anak bernama Puspalawa dengan kekuatan sihir Hayam Canggong (bait 422,455,503) (Noorduyn, 2009:545).

420 Tucap aki Hayam Canggong

Eukeur ngayun-ngayun boncah

T(e)her maca Watang Ageung

Ruana to(ng)goy/milangan/10/

Dingaranan Bujanggalawa

500 Basa aing ngasuh boncah Horeng nuturkeun ka cai Mantara aing milangan Na sanghiang Watang Ageung Si utun hanteu disiar 
(Noorduyn,2009:222-223)

Tersebutlah kakek Hayam
Canggong
Sedang mengayun-ayun bayi
Kemudian membaca Watang
Ageung
Tampak asyik membaca.
Yang namanya Bujanggalawa

Ketika aku mengasuh anak itu Ternyata mengikuti tuan ke sungai Lalu aku membaca mantera Dalam sanghiang Watang Ageung Ananda tidak kucari

Uraian lebih lanjut mengenai "kitab suci" Sanghiyang Watang Ageung tidak diketahui, kecuali penulisnya yaitu Sang Kandiawan atau Sang Layuwatang. Di samping itu, beberapa naskah pun hanya mencantumkan namanya saja.

\section{2) Sanghyang Siksa}

Dalam naskah CP itu tercatat empat orang raja yang dikatakan berpegang kepada ajaran Sanghyang Siksa, yaitu Rahyang Sanjaya, Rahyang Manisri, Prabu Darmasiksa, dan Prabu Jayadewata.

Ketika membicarakan Rahyang Sanjaya, naskah CP antara lain mencatat, /13/ ( ... ) pun rahyang sanjaya, rhyangtang kuku ti monang tapana, mikukuh sanghyang darma kalawan sanghyang siksa ( ... ) 'Rahyang Sanjaya, dan Rahyangtang Kuku berhasil dalam tugasnya karena mereka menaati Sanghyang Darma dan Sanghyang Siksa'.

Salah seorang raja Sunda yang cukup lama memerintah adalah Sang Manisri, sebagaimana diberitakan, /15/ ( ... ) sang manistri lawas adêg ratu gênêp puluh tahun, kena isis di sanghyang siksa (...) 'Sang Manisri menjadi raja selama 60 tahun karena ia menguasai Sanghyang Siksa'.

Berita berikutnya sehubungan dengan Prabu Darmasiksa yang memerintah justru sangat lama (150 tahun menurut CP, 122 tahun menurut Pustaka Rajyarajya i Bhumi Nusantara), /17/ (...) ti sang wiku nu ngawakan jati sunda, mikukuh sanghyang darma ngawakan sanghyang siksa (...) 'Dari sang pendeta yang menjalankan ajaran Sunda asli, berpegang teguh kepada Sanghyang Darma dan menjalankan ajaran Sanghyang Siksa'.

Akhimya, ketika memberitakan Prabu Jayadewata yang berkuasa selama 39 tahun, CP mencatat, /19/ tan krêta ja laki-bi dina urang reya, ja loba di sanghyang siksa 'Tidak sejahtera (bahagia) kehidupan keluarga orang banyak karena mereka banyak (yang) melanggar (ajaran) Sanghyang Siksa' (Ayatroehaedi 1995:70).

Ajaran pertama yang disampaikan naskah SSKK berkenaan dengan fungsi dasaindria, yaitu sepuluh indra utama yang dimiliki setiap orang. Menurut naskah itu, /1/ ( ... ) ini byakta: beuli ulah barang denge mo ma nu sieup didenge kenana dora bancana, sangkan ulah riemu mala na lunas papa naraka; hengan lamun kapahayu ma sinengguh utama ti pangreungeu. mata ulah barang deulo mo ma nu sieup dideuleu kenana dora bancana, sangkan ulah nетu mala na lunas papa naraka; hengan lamun kapahayu ma sinengguh utama ning deuleu ( ... ) 'Inilah kenyataannya: Telinga jangan mendengarkan (sesuatu) yang tidak layak didengar karena menjadi pintu bencana, penyebab kita mendapat celaka di dasar kenistaan neraka; namun kalau telinga terpelihara, kita akan mendapat keutamaan dalam pendengaran. Mata jangan sembarang melihat (sesuatu) yang tidak layak dilihat karena menjadi pintu bencana, penyebab kita mendapat celaka di dasar kenistaan neraka, namun bila mata terpelihara, kita akan mendapat keutamaan dalam penglihatan.

Setelah telinga dan mata, indra lain yang harus dipelihara dengan baik adalah kulit 'kulit', letah 'lidah', irung 'hidung', sungut 'mulut', leungeun 'lengan, tangan', suku 'kaki', payu 'lubang dubur', dan baga purusa (baga 'kemaluan perempuan' dan purusa 'kemaluan laki-laki). Jika kesepuluh pintu nafsu itu sudah terpelihara, maka rampes twahna urang reya, maka nguni 
twah sang dewa ratu 'sempurnalah perbuatan orang banyak, demikian pula perbuatan sang raja'.

Ajaran yang kedua berkenaan dengan masalah ketaatan dan kewajiban setiap orang sebagaimana diamanatkan oleh sang budiman sejati: /2/ ( ... ) anak bakti di bapa, ewe bakti di laki, hulun bakti di pacandaan, sisya bakti di guru, wang tani bakti di wado, wado bakti di mantri, mantri bakti di nu nangganan, nu nangganan bakti di mangkubumi, mangkubumi bakti di ratu, ratu bakti di dewata, dewata bakti di hyang. 'Anak tunduk kepada bapak, istri tunduk kepada suami, hamba tunduk kepada majikan, siswa tunduk kepada guru, petani tunduk kepada wado, wado tunduk kepada mantri, mantri tunduk kepada "yang menangani", "yang menangani" tunduk kepada mangkubumi, mangkubumi tunduk kepada raja, raja tunduk kepada dewata, dewata tunduk kepada hyang'.

Ajaran ketiga berkenaan dengan bagaimana cara melaksanakan tugas atau darma setiap orang. Melaksanakan tugas itu ternyata terdiri atas dua hal, yang pertama yang berupa keharusan, sedangkan yang kedua berupa larangan. Naskah SSKK menyebutkan bahwa /4/ ( ... ) ini karma ning hulun, saka jalan urang hulun, karma ma ngarana pibudion, tingkah paripolah saka jalan ngaranya. maka takut maka jarot, maka atong maka toang di tingkah di pitwahon, di .ulah di pisabdaan 'Ini pekerjaan hamba untuk jalan kita mengabdi. Pekerjaan itu disebut akal budi, tingkah itu namanya jalan. Hendaknya takut, berhati-hati, hormat sopan dalam tingkah, dalam perbuatan, dalam ulah dan perkataan'. Jika kita tetap setia dalam pengabdian, akan pulih dari noda yang sepuluh, pasti terhapus dosa dan hilang penderitaan bersua dengan kebahagiaan.

Ajaran keempat berkaitan dengan kriteria pemimpin. Pada naskah yang dimaksud terdapat istilah Parigeuing dan Dasa Pasanta yang menguraikan bagaimana seorang pemimpin berlaku.
Parigeuing adalah pemimpin yang bisa memerintah atau menyuruh seseorang dengan ucapan menyejukkan hati dan tidak menjengkelkan orang yang diperintah atau disuruhnya itu.

Adapun Dasa Pasanta merupakan uraian atau semacam "juklak" (petunjuk pelaksaanan) dari Parigeuing. Dasa Pasanta berarti sepuluh penentram. Maksudnya, bagaimana caranya menentramkan hati orang yang diperintah agar dalam melaksanakan tugas kerjanya itu disertai kerelaan dan semangat kerja yang tinggi.

Sepuluh penentram yang dimaksud adalah sebagai berikut.

(1) Guna (berguna) : Perintah harus jelas manfaatnya;

(2) Rama / Ramah : Perintah disampaikan dengan kewajaran dan keramahan.

(3) Hook (kekaguman) : Perintah harus menimbulkan kekaguman pada diri yang diperintah.

(4) Pesok (memikat): Perintah menimbulkan keterpikatan hati.

(5) Asih (pengasih): Perintah harus disertai kewelas-asihan.

(6) Karunia : Parintah dirasakan sebagai karunia, atau kepercayaan pimpinan.

(7) Mupreruk / Mukpruk (membujuk) : Seorang pemimpin harus bisa membujuk dan mengambil hati bawahannya.

(8) Ngulas (mengulas): Pemimpin harus pandai berkomentar yang baik terhadap hasil pekerjaan bawahannya.

(9) Nyecep (menentramkan hati): pemimpin harus menentramkan hati bawahannya.

(10) Ngala angen (mengambil hati): Pemimpin harus dapat mengambil simpati bawahan. Sifat ini tentunya akan melahirkan tanggung jawab yang besar dari orang yang disuruhnya.

\section{3 ) Ajaran Prabuguru Darmasiksa}

Diganti ku Sang Rakean Darmasiksa, titisan Sanghiang Wisnu, nya eta nu ngawangun sanghiang binajapanti. $N u$ ngajadikeun para kabuyutan ti sang rama, 
ti sang resi, ti sang disri, ti sang tarahan tina parahiangan. "Tina naon berkahna?" Ti sang wiku nu mibanda Sunda pituin, mituhu Sanghiang Darma, ngamalkeun Sanghiang Siksa. (CP XVII, Atja:1968)

(Digantikan lagi oleh Sang Rakeyan Darmasiksa, penjelmaan Sanghyang Wisnu. Dialah yang membuat panti pendidikan, yang menjadikan tempat-tempat suci bagi sang rama, sang resi, sang disri, sang tarahan di tempattempat pemujaan. Dari mana mengetahuinya? dari para wiku yang melaksanakan keaslian Sunda, berpegang teguh kepada Sanghyang Darma, mengamalkan Sanghyang Siksa).

Ada dua tokoh raja dalam naskah CP yang menonjol dan dianggap berhasil dalam melaksanakan ajaran siksa kandang karesian. Kedua tokoh yang dimaksud adalah Prabu Darmasiksa dan Mahaprabu Niskala Wastu Kancana. Tokoh pertama berkaitan dengan kerajaan Saunggalah di Kuningan dan tokoh kedua berkaitan dengan Kerajaan Kawali.

Setelah ditelusuri, ternyata Prabuguru Darmasiksa (Danasasmita, 1983-1984 Jilid Ketiga: 18-23). adalah tokoh yang meletakkan dasar-dasar Pandangan Hidup/Visi ajaran hidup secara tertulis berupa nasihat. Naskahnya disebut sebagai Amanat Dari Galunggung, disebut juga sebagai Naskah Ciburuy (nama tempat di Garut Selatan tempat ditemukan naskah Galunggung tsb.) atau disebut pula kropak No.632, ditulis pada daun nipah sebanyak 6 lembar yang terdiri atas 12 halaman; menggunakan aksara Sunda Kuna (Danasasmita, 1987: 6).

Berikut adalah sebagian rangkuman amanat-amanat Prabuguru Darmasiksa, khususnya amanat yang berkaitan dengan kepemimpinan.

a) Perlu kewaspadaan akan kemungkinan direbutnya kemuliaan (kewibawaan dan kekuasaan) serta kejayaan bangsa oleh orang asing.

b) Lebih berharga kulit lasun (musang) yang berada di tempat sampah daripada raja putra yang tidak bisa mempertahankan kabuyutan/ tanah airnya

c) Orang yang keras kepala, yaitu orang yang ingin menang sendiri, tidak mau mendengar nasihat ayah-bunda, tidak mengindahkan ajaran moral (patikrama).

d) Peliharalah kesempurnaan agama, pegangan hidup kita semua

e) Kejujuran dan kebenaran itu ada pada diri sendiri

f) Pengisi neraka itu adalah manusia yang suka mengeluh karena malas beramal; banyak yang diinginkannya tetapi tidak tersedia di rumahnya; akhirnya meminta-minta kepada orang lain.

g) Amal yang baik seperti ilmu padi makin lama makin merunduk karena penuh bernas.

1) Ada dahulu (masa lampau) maka ada sekarang (masa kini), tidak akan ada masa sekarang kalau tidak ada masa yang terdahulu. Ada pokok (pohon) ada pula batangnya, tidak akan ada batang kalau tidak ada pokoknya.

n) Tirulah wujudnya air di sungai, terus mengalir dalam alur yang dilaluinya. Itulah yang tidak sia-sia. Pusatkan perhatian kepada cita-cita yang diinginkan. Itulah yang disebut dengan kesempurnaan dan keindahan.

o) Perilaku Positif diantaranya:

(1)Harus bersama-sama mengerjakan kemuliaan, melalui: perbuatan, ucapan dan itikad yang bijaksana; (2) Perbuatan, ucapan dan tekad harus bijaksana; (3) Harus bersifat hakiki, bersungguh-sungguh, memikat hati, suka mengalah, murah senyum, berseri hati dan mantap bicara, (4) Perhatian harus selalu tertuju/terfokus pada alur yang dituju. (5) Senang akan keelokan/keindahan. (6) Kuat pendirian tidak mudah terpengaruh. (7) Jangan mendengarkan ucapan-ucapan yang buruk. (8) Konsentrasikan perhatian pada cita-cita yang ingin dicapai

p) Perilaku Negatif: 
(1) Jangan merasa diri yang paling benar, paling jujur, paling lurus. (2) Jangan menikah dengan saudara.(3) Jangan membunuh yang tidak berdosa. (4) Jangan merampas hak orang lain. (5) Jangan menyakiti orang yang tidak bersalah. (6) Jangan saling mencurigai.(7) Jangan memarahi orang yang tidak bersalah. (8) Jangan tidak berbakti kepada leluhur yang telah mampu mempertahankan tanahnya (kabuyutannya) pada zamannya. (9) Jangan berebut kedudukan. (10) Jangan berebut penghasilan.(11) Jangan berebut hadiah. (12) Jangan berkata berteriak, menyindir, menjelekkan sesama orang dan jangan mengada-ada. (13) pemalas, (14) keras kepala, (15) pandir/bodoh, (16) perenung, (17) pemalu, (18) mudah tersinggung/ babarian, (19) lamban, (20) kurang semangat, (21) gemar tiduran, (22) lengah, (23) tidak tertib

\section{4) Ajaran Mahaprabu Nila Wastu Kancana}

Wastu Kancana naik tahta dalam usia 23 tahun menggantikan Bunisora dengan gelar Mahaprabu Niskala Wastu Kancana atau Praburesi Buanatunggaldewata (Danasasmita,19831984 Jilid Ketiga: 38). Ajaran yang ditingggalkanya untuk kita semua adalah membiasakan diri berbuat kebajikan (pakenal gawe rahayu) dan membiasakan diri berbuat kesejahteraan sejati (pakena kereta bener) adalah sumber kejayaan dan kesentosaan negara. Uraian tentang kebajikan dan kesejahteraan sejati itu terdapat dalam kropak 632 (Amanat dari Galunggung) dan kropak 630 (Sanghyang Siksakandang Karesian). Salah satu kunci ke arah kesejahteraan sejati itu dalam kropak 630 lembar 26 dan 27 diuraikan sebagai berikut.

Teguhkeun, pageuhkeun sahinga ning tuhu, pepet byakta warta manah, mana kreta na bwana, mana hayu ikang jagat kena twah ning janma kapahayu
(Teguhkan, kukuhkan batas-batas kebenaran, penuhkan kenyataan niat baik dalam jiwa, maka akan sejahteralah dunia, maka akan sentosalah jagat ini sebab perbuatan manusia yang penuh kebajikan).

Nguni sang pandita kalawan sang dewaratu pageuh ngretakeun ing bwana, nya mana kreta lor kidul kulon wetan sakasangga dening pretiwi sakakurung dening akasa, pahi manghurip ikang sarwo janma kabeh.

(Demikianlah seharusnya, pendeta dan raja harus teguh membina kesejahteraan di dunia, maka akan sejahteralah di utara selatan barat dan timur, di seluruh hamparan bumi dan seluruh naungan langit, sempurnalah kehidupan seluruh umat manusia).

Sanghiyang Siksakandang Karesian itu memuat inti ajaran bahwa bila tiap orang berpegang teguh kepada kebenaran dalam menjalankan tugasnya masing-masing, akan tercapailah kesejahteraan sejati. Kesejahteraan batin karena tidak mengingkari kebenaran dan kesejahteraan lahir karena menjalankan tugas dengan penuh kesungguhan akan memberikan prestasi maksimal. Jujur dan sungguh-sungguh dalam pelaksanaan tugas. Itulah yang diwasiatkan Prabu Wastu kepada nu pandeuri (mereka yang hidup sesudah dia).

Semua itu perlu agar heubeul jaya dina buana (lama berjaya di dunia) dan agar nanjeur na juritan (tetap unggul dalam perang). Bila konsep "kerta"- nya dijalankan benar-benar tentu akan tercapai ketahanan dalam segala segi kehidupan kenegaraan.

Dalam lembar 13 dijelaskan bagi seseorang yang melakukan tugas demi kebajikan dan kesejahteraan harus rela dan bersedia menerima kritik dari orang lain terhadap hasil karyanya.

"Lamun aya nu meda urang, aku sapameda sakalih" (kalau ada yang memberi kritik kepada kita, terimalah 
kritik orang lain itu). Anggaplah hal itu sebagai penawar (obat).

Pameda (kritik) itu ibarat air untuk mandi bagi orang yang sedang dekil, ibarat minyak bagi orang yang burik, bagaikan nasi bagi orang yang lapar, bagaikan air minum bagi orang yang sedang haus, dan ibarat sirih-pinang (sepaheun) bagi orang yang sedang kesal. Itulah panca parisuda (lima penawar) yang terdapat dalam kritik. Bila kita bersedia menerimanya budi kita akan makin padat berisi "kangken pare beurat sangga" (seperti padi yang runduk karena berat berisi).

Masa kemakmuran yang telah dicontohkan oleh Prabu Wastu itu secara hiperbolis dilukiskan oleh penulis Carita Parahiyangan. Jangankan manusia, apah (air), teja (cahaya), bayu (angin), akasa (langit) serta sang bu (eter) merasa betah berada di bawah naungan pemerintahannya. Raja itu dipandang sebagai tokoh teladan karena penulis itu menganjurkan, "sugan aya nu dek nurutan inya twah nu surup ka nusalarang. (Barangkali ada yang hendak meniru perilaku yang mendiang ke Nusalarang). Wastu Kancana dipusarakan di Nusalarang. (Danasasmita,1983-1984 Jilid Ketiga: 41).

Keteladanan Wastu Kancana sangat luar biasa. Inilah gambaran tokoh Wastu Kancana menurut penulis Carita Parahiyangan.

Ayana seuweu Prebu Wangi, ngaranna inyana Prebu Niskala Wastu Kancana nu surup di Nusa Larang ring Giri Wanakusuma. Lawasnya ratu saratus opat taliun kena rampes na agama, krêtayuga.

Tandang paompo ywa pon kenana ratu eleh ku satmata, nurut nu ngasuh, Hiyang Bunisora nu surup ka Gêgêr Omas, Batara Guru di Jampang. Sakitu nu diturut ku nu mawa lemah-cai.

Sakitu, sugan aya nu dek nurutan inya twah nu surup ka Nusa Larang. Daek eleh ku satmata-Manana krêtayuga, eleh ku nu ngasuh.
Nya mana sang rama enak amangan, sang resi enak ngaresianana, ngawakan na purbatisti-purbajati. Sang disri enak masini ngawakan na manusasana, ngaduman alas pari alas. Ku beet hamo diukih, ku gêde hamo diukih. Nya mana sang tarahan enak lalayaran ngawakan manurajasasana. Sanghiyang apah, teja, bayu, akasa, sang bu enak-enak ngalungguh di sanghiyang jagat palaka.

Ngawakan sanghiyang rajasasana, angadêg di sanghiyang linggawêsi, brata siya puja tan palum.

Sang wiku enak ngadewasasana, ngawakan sanghiyang watang ageung, enak mangadeg manurajasuniya.

(Ada seorang putera Prabu Wangi (Prabu Maharaja) bernama Prabu Niskala Wastu Kancana yang mendiang di Nusa Larang, di Bukit Wanakusuma. la memerintah selama 104 tahun karena sempurna mengamalkan agama, maka tercapailah keadaan yang serba sejahtera.

Tindakannya seperti orang dewasa walaupun usianya masih muda karena raja tunduk (kepada tuntunan) satmata (Bunisora), mengikuti (petunjuk) pengasuhnya, yaitu Hiyang Bunisora yang mendiang di Geger Omas alias Batara Guru di Jampang. (Tokoh) itulah yang diikuti oleh penguasa tanah-air.

Demikianlah, semoga ada yang berhasrat meniru perilaku yang mendiang ke Nusa Larang, mau menuruti satmata. Tercapailah keadaan serba-sejahtera karena (raja) mengikuti pengasuhnya.

Dengan demikian, sang rama (sesepuh desa) dapat leluasa mengemong (membimbing) rakyat, sang resi dapat leluasa melaksanakan tugas sebagai pendeta mengamalkan adat-istiadat warisan leluhur. Sang disri dapat leluasa mengatur pembagian wilayah, mengamalkan hukum Manu, membagikan hutan dan daerah sekitarnya. Yang kecil mau pun yang besar tidak ada yang menggugat. Karena itulah, sang tarahan dapat leluasa mengarungi perairan mengamalkan peraturan raja. Air, cahaya, 
angin, angkasa, "eter" merasa betah berada dalam naungan sang pelindung dunia. (Wastu Kancana) menerapkan undangundang kerajaan, menetap (?) di sanghiyang linggawesi (nama ajaran atau Astana Gede?). la melakukan tapa dan puja tiada henti-hentinya.

Sang Wiku (Wastu Kancana) dengan leluasa melaksanakan undang-undang dewa, mengamalkan sanghiyang watang ageung (ajaran yang disusun oleh Sang Kandiawan, ayahanda Wretikandayun). Dengan tenang ia melaksanakan manurajasuniya (bertapa setelah turun tahta).

\section{PEN UTUP}

Ajaran kepemimpinan dalam teks naskah Carita Parahiyangan secara tidak langsung mengisyaratkan persyaratan yang harus dipenuhi oleh seorang pemimpin, yaitu: (1) sehat jasmani dan rohani. Kecacatan tubuh menyebabkan kewibawaan sebagai raja akan berkurang, bahkan tidak mustahil menjadi bahan tertawaan sekaligus pelecehan; (2) memiliki kekuatan atau keterampilan yang dapat menunjukkan keunggulan dibandingkan dengan manusia lain; (3) pendidikan yang akan memengaruhi pengambilan kebijakan sekaligus membuktikan kehebatan sang guru dalam mendidik siswanya; (4) musyawarah sebagai jalan mencapai kesepakatan dalam mengambil keputusan.

Ajaran Siksakandang Karesian dan Amanat dari Galunggung menjadi rujukan para raja Pra-Islam di Jawa Barat dalam tata cara memimpin. Kedua ajaran tersebut menjadi ukuran dalam menunjukkan eksistensi sebuah kerajaannya.

Pemimpin yang baik dan berhasil lebih disebabkan patuh dan taat pada ajaran (agama) yang dianutnya. Ajaran Watang agung walau hanya catatan belaka, namun para ahli meyakini "nama/sebutan watang agung merujuk pada sebuah ajaran tertentu di masa lalu.
Dalam ajaran Sanghyang Siksa terdapat (1) dasaindria, yaitu sepuluh indra utama yang dimiliki setiap orang; (2) berkenaan dengan masalah ketaatan dan kewajiban setiap orang, (3) cara melaksanakan tugas atau darma setiap orang, (4) berkaitan dengan kriteria pemimpin yaitu Parigeuing dan Dasa Pasanta yang menguraikan bagaimana seorang pemimpin berperilaku. Dasa Prasanta tersebut, apabila kita cermati, kaidahnya berpijak kepada kuantitas dan kualitas hubungan antarmanusia, tetapi tidak dalam kondisi yang kaku dan otoriter. Proses komunikasinya tetap menggunakan asas silih asih, silih asah, dan silih asuh.

Di samping hal di atas, perlu juga diselami ajaran Prabu Darmasiksa mengenai karakter-karakter positif dan negatif di dalam menjalankan kepemimpinan. Ajaran moral dan agama melarut dan membentuk sebuah karakter yang kemudian merefleksikan diri dalam wujud ajaran kepemimpinan.

Bentuk konkret pengamalan Siksakandang Karesian digambarkan oleh tokoh Wastukancana yang telah berhasil membangun Kerajaan Sunda di Kawali. Ajaran yang ditingggalkanya untuk kita semua adalah membiasakan diri berbuat kebajikan (pakena gawe rahayu) dan membiasakan diri berbuat kesejahteraan sejati (pakena kereta bener) adalah sumber kejayaan dan kesentosaan negara. Catatan masa lalu menggambarkan keruntuhan atau penggantian tahta kerajaan disebabkan perilaku (ahlak) yang tidak sesuai dengan ajaran, dalam hal ini ajaran siksa kandang. Namun sebaliknya, raja-raja yang sukses mengemban amanat rakyatnya adalah mereka yang mengamalkan ajaran siksa kandang. 


\section{DAFTAR SUMBER}

Adiwimarta, Sri Sukaesih. 1993.

Unsur-unsur Ajaran dalam Kakawin Pārthayajňa. Jakarta: Program Pascasarjana Universitas Indonesia.

Atja. 1968.

Carita Parahiyangan. Titilar Karuhun Sunda. Bandung: Nusalarang.

1990.

"Carita Parahiyangan Versi Sumedang dan Cirebon". Pikiran Rakyat, 30Januari 1990, hlm. 8.

Atja dan Saleh Danasasmita. 1981.

Carita Parahiyangan: Transkripsi, Terjemahan dan Catatan. Bandung: Proyek Pengembangan Permuseuman Jawa Barat.

Ayatrohaedi dan Sri Saadah. 1995.

Janiniskala: Kehidupan Kerohanian Masyarakat Sunda Sebelum Islam. Jakarta: Proyek Pengkajian dan Pembinaan Nilai-nilai Budaya Pusat Direktorat Sejarah dan Nilai Tradisional Direktorat Jenderal Kebudayaan Departemen Pendidikan dan Kebudayaan.

Danadibrata, R., 2006.

Kamus Basa Sunda. Bandung: Kiblat.

Danasasmita, Saleh; Yoseph Iskandar; Enoch Atmadibrata.1983-1984.

Rintisan Penelusuran Masa Silam Sejarah Jawa Barat, Jilid KetigaKeempat. Proyek Penerbitan Sejarah Jawa Barat Pemerintah Propinsi Daerah Tingkat I Jawa Barat.

Danasasmita, Saleh dan Anis Djatisunda. 1986. Kehidupan Masyarakat Kanekes. Bandung: Bagian Proyek Penelitian dan Pengkajian Kebudayaan Sunda (Sundanologi) Ditjen Kebudayaan Depdikbud.

Danasasmita, Saleh; Ayatrohaedi; Tien Wartini; Undang Ahmad Darsa. 1987.

Sewakadarma, Sanghyang Siksa kandang Karesian, Amanat Galunggung: Transkripsi dan Terjemahan. Bandung: Bagian Proyek Penelitian dan Pengkajian Kebudayaan Sunda (Sundanologi) Ditjen Kebudayaan Depdikbud.
Departemen Pendidikan Nasional. 2013.

Kamus Besar Bahasa Indonesia. Edisi Keempat. Jakarta: Gramedia.

Ekajati, Edi S. 1982.

Cerita Dipati Ukur: Karya Sastera Sejarah Sunda. Jakarta: Pustaka Jaya.

Direktorat Jenderal Nilai Budaya Seni dan Film Direktorat Kepercayaan Terhadap Tuhan Yang Maha Esa. 2010. Ensiklopedi: Kepercayaan Terhadap Tuhan Yang Maha Esa.

Ikram, Achadiati. 1997.

Filologia Nusantara. Jakarta: Pustaka Jaya.

LBSS. 1995.

Kamus Umum Basa Sunda. Bandung: Tarate.

Noorduyn, J. dan A.Teeuw. 2009. Tiga Pesona Sunda Kuna. Jakarta: Pustaka Jaya.

Soekanto, Soerjono,1988. Sosiologi: Suatu Pengantar. Jakarta: CV Rajawali.

Supardi, Imam. Tt.

Metodologi Penelitian. Bandung: Program Pascasarjana Universitas Padjadjaran.

Teeuw, A. 1983. Membaca dan Menilai Sastra. Jakarta: Gramedia. 